\title{
Testing the occurrence of Late Jurassic true polar wander using the La Negra volcanics of northern Chile
}

\author{
Roger R. Fu ${ }^{\mathrm{a}, *}$, Dennis V. Kent ${ }^{\mathrm{b}, \mathrm{c}}$, Sidney R. Hemming ${ }^{\mathrm{b}}$, Pablo Gutiérrez ${ }^{\mathrm{d}}$, \\ Jessica R. Creveling ${ }^{\mathrm{e}}$
}

a Department of Earth and Planetary Sciences, Harvard University, 20 Oxford St., Cambridge, MA 02138, USA
b Lamont-Doherty Earth Observatory, Columbia University, 61 Route 9W, Palisades, NY 10964, USA
c Department of Earth and Planetary Science, Rutgers University, 610 Taylor Rd, Piscataway, NY 08854, USA
d Departamento de Ciencias Geológicas, Universidad Catolica del Norte, Avenida Angamos 0610, Antofagasta, Chile
e College of Earth, Ocean, and Atmospheric Sciences, Oregon State University, 104 CEOAS Admin Building, Corvallis, OR, USA

\section{A R T I C L E I N F O}

\section{Article history:}

Received 28 February 2019

Received in revised form 27 August 2019

Accepted 9 September 2019

Available online $\mathrm{xxxx}$

Editor: B. Buffett

\section{Keywords:}

paleomagnetism

geodynamics

tectonics

geophysics

geochronology

Jurassic Period

\begin{abstract}
A B S T R A C T
True polar wander (TPW) is the reorientation of the crust-mantle system driven by the redistribution of masses in the mantle and on the Earth's surface. In the ideal case, characterization of TPW requires paleomagnetic constraints on the motion of all major plates and independent reconstructions of relative plate positions. While such complete datasets are absent for pre-Mesozoic TPW inferences due to the absence of oceanic plates, they are available for the Late Jurassic (165-145 Ma) "monster shift", a $\sim 30^{\circ}$ amplitude proposed TPW event. Here we perform paleomagnetic sampling and Ar-Ar geochronology on the La Negra volcanics of Northern Chile, producing two new paleomagnetic poles with ages $165.8 \pm$ $1.8 \mathrm{Ma}\left(1 \sigma ; 84.3^{\circ} \mathrm{N} 0.9^{\circ} \mathrm{E} ; \alpha_{95}=7.6^{\circ} ; N=28\right)$ and $152.8 \pm 0.8 \mathrm{Ma}\left(84.5^{\circ} \mathrm{N} 256.4^{\circ} \mathrm{E} ; \alpha_{95}=10.8^{\circ}\right.$; $N=18$ ). By combining these data with other recently published results, we compute a net lithospheric rotation of $25.3^{\circ} \pm 7.3^{\circ}(1 \sigma)$ at a mean rate of $1.21^{\circ} \pm 0.35^{\circ} \mathrm{My}^{-1}$ between 170 and $145 \mathrm{Ma}$ with a peak rate of $1.46^{\circ} \pm 0.65^{\circ} \mathrm{My}^{-1}$ between 160 and $145 \mathrm{Ma}$. These rates are consistent with inferences from the Pacific Plate, implying true whole lithosphere rotation. Given coherent motion involving the entire lithosphere, we conclude that the Earth underwent rapid TPW between approximately 165 and $145 \mathrm{Ma}$, potentially driven by the cessation of subduction along the western North American margin.
\end{abstract}

(C) 2019 Elsevier B.V. All rights reserved.

\section{Introduction}

True polar wander, or TPW, is the reorientation of the entire crust-mantle system of a planet with respect to its rotation axis (Gold, 1955). Redistribution of mass on the Earth's surface or in the deep interior can change the energetically favorable axis of rotation, which tends to align with the axis of highest moment of inertia. On the modern Earth, a combination of modern melting due to climate warming, ongoing effects from the last ice age cycle, and longer timescale mantle processes induce TPW at the rate of $\sim 1^{\circ} \mathrm{My}^{-1}$ (Gordon, 1995; Gross and Vondrak, 1999), although the total amplitude of deglaciation-induced TPW is expected to be less than $1^{\circ}$ (Mitrovica et al., 2015).

Observations that constrain TPW in the geological past can contribute to knowledge of both mantle dynamics and surface environmental change (Evans, 2003). The orientation of the TPW axis

\footnotetext{
* Corresponding author.

E-mail address: rogerfu@fas.harvard.edu (R.R. Fu).
}

and the rate and total amplitude of rotation are influenced by the viscosity of the mantle, the distribution of mantle mass anomalies, and the elastic thickness of the lithosphere (Tsai and Stevenson, 2007; Creveling et al., 2012; Greff-Lefftz and Besse, 2014; Chan et al., 2014). Inferences of past TPW have therefore been used to constrain the stability of deep mantle density structure and the occurrence of subduction and mantle plumes through time (Robert et al., 2018). At the same time, studies of paleoenvironments and sea-level records motivate robust determinations of TPW due to the potentially large associated shifts in latitude, local climate, and local sea-level with amplitudes of up to $100 \mathrm{~m}$ (Mound and Mitrovica, 1998; Mound et al., 1999; Muttoni and Kent, 2016).

Temporally resolved paleomagnetic data underpin all inferences of rapid, large amplitude TPW events in the geological past. However, the translation and rotation of tectonic plates inferred from paleomagnetism may instead arise from relative motion over the underlying mantle, referred to hereafter as "plate tectonic motions". Reliable constraints on past TPW events must be able to deconvolve the contributions of TPW from plate tectonic motions. 
Observation of coherent rotation of all sampled tectonic plates alone is insufficient to identify TPW because the entire lithospheric frame of reference may have a velocity relative to the underlying mantle (i.e., spherical harmonic degree 1 plate tectonics motion). However, such relative motion between the entire lithosphere and the mantle is believed to be slow $\left[\leq 0.2^{\circ} \mathrm{My}^{-1}\right.$; Jurdy and Van der Voo, 1974; O'Connell and Hager, 1990; Rudolph and Zhong, 2014]. As such, observations of rapid $\left(\gg 0.2^{\circ} \mathrm{My}^{-1}\right.$ ) net rotation of the lithosphere have been interpreted as robust evidence for TPW [e.g., Van der Voo, 1994; Maloof et al., 2006; Mitchell et al., 2010]. Note here we use the term "net lithospheric rotation" in the kinematic sense, describing the observed rotation of the whole Earth surface about an equatorial axis. This usage contrasts with some published works where "net lithospheric rotation" refers specifically to plate tectonics motion of the whole lithosphere over the mantle [e.g., Torsvik et al., 2010].

Quantifying net lithosphere rotation requires high-quality paleomagnetic data from a large fraction of the Earth's lithospheric plates in conjunction with robust plate reconstructions that provide their relative longitudinal positions. Critically, paleomagnetic datasets prior to 200 Ma lack any coverage of the Earth's oceanic plates, which likely covered more than $50 \%$ of the Earth's surface area. Hence, pre-200 Ma paleomagnetic data can only quantify net continental rotation, which must then be extrapolated by assumption to net rotation of the entire lithosphere to constrain TPW. Likewise, significant uncertainties arise in paleogeographic reconstructions of continents prior to $\sim 250 \mathrm{Ma}$ (Muttoni et al., 2003), with radically different interpretations proposed by middle Neoproterozoic time [ $750 \mathrm{Ma}$; Swanson-Hysell et al., 2012].

As such, quantification of the true net lithospheric rotation rate, not only the net continental rotation rate, is currently feasible only during the past $\sim 200 \mathrm{Ma}$. Therefore, the highest confidence identifications of TPW are possible only during this recent time interval. Thorough understanding of such a recent TPW event, complete with precise inferences of TPW duration and path, can be used to analyze the geophysical causes of TPW and inform the interpretation of TPW and its implications for mantle dynamics in the deeper past.

Several compilations of paleomagnetic data have argued for large amplitude TPW occurring during the Jurassic Period (201-145 Ma). Using paleogeographical reconstructions based on marine magnetic anomalies, previous studies have rotated contemporaneous paleomagnetic poles from different continents into composite poles within a single coordinate system (Besse and Courtillot, 2002; Torsvik et al., 2008; Kent and Irving, 2010; Torsvik et al., 2012). A series of such composite poles at different ages make up a composite apparent polar wander (APW) path that can be used to quantify the net rotation of all continental plates whose relative positions in the ancient past are known from well-dated marine magnetic lineations.

Two recently published composite APW paths support the idea that net continental rotation was anomalously rapid during the Jurassic Period (Kent and Irving, 2010; Torsvik et al., 2012). Both studies infer total rotations of $30.5^{\circ}-39.9^{\circ}$ between 200 and $140 \mathrm{Ma}$ and broadly agree on an equatorial rotation axis near West Africa. However, while Torsvik et al. (2012) favored steady rotation at a rate of $\leq 0.8^{\circ} \mathrm{My}^{-1}$ throughout the Jurassic, Kent and Irving (2010) argued for a phase of rapid rotation between 160 and 145 $\mathrm{Ma}$ at rates up to $2.0^{\circ} \mathrm{My}^{-1}$, which they termed the Jurassic "monster shift." These differences in the maximum rate and duration of net continental rotation imply dramatically different geodynamical conditions in the mantle and the lithosphere and/or different geometry of the Earth's non-equilibrium figure [e.g., Creveling et al., 2012].

The key differences in the two compilations stem from the choice of included paleomagnetic poles. Torsvik et al. (2012) com- puted a quality-weighted mean of all available igneous and sedimentary paleomagnetic poles whereas Kent and Irving (2010) adopted only poles derived from igneous or inclination errorcorrected sedimentary rocks. Furthermore, the latter compilation excluded all poles from the Colorado Plateau, which are predominantly based on sedimentary rocks that have not been corrected for inclination shallowing and may have undergone clockwise vertical axis rotation with respect to cratonic North America by $4^{\circ}$ to $>10^{\circ}$ (Steiner, 1988; Bryan and Gordon, 1990; Kent and Witte, 1993; Steiner, 2003). As a result, the composite APW path of Torsvik et al. (2012) may be susceptible to systematic biases from unreliable paleomagnetic results while that of Kent and Irving (2010) may suffer from the small number of constituent poles, including only five poles in the critical 165-140 Ma interval.

More recently published paleomagnetic data have contributed additional constraints on net continental rotation in the Late Jurassic. Two poles based on well-dated North America kimberlites (Kent et al., 2015) combined with an updated pole for the igneous Chon Aike Formation of Patagonia reinforce the position of the composite APW path at 155-157 Ma (Ruiz González et al., 2019), although these poles do not strongly distinguish between the two previously published composite APW paths. Meanwhile, inclination shallowing correction of sedimentary rock-derived paleomagnetic poles from Adria and North Africa support rapid continental rotation with rates up to $2.5^{\circ} \mathrm{My}^{-1}$ between $\sim 183$ and $145 \mathrm{Ma}$ (Muttoni et al., 2013; Muttoni and Kent, 2019). Finally, a paleomagnetic study of the Ocean Drilling Program (ODP) core 801B showed that the Pacific Plate, which was kinematically coupled to all the major oceanic plates of the Pacific Basin, likely experienced a rapid northward motion in the 157-147 Ma interval (Fu and Kent, 2018). If corroborated by a refined continental composite APW path, this apparent consistency between the inferred motions of the continental and Pacific Basin plates would provide strong evidence that the monster shift represents rotation of the entire lithosphere-mantle frame.

In this work, we present a refined net rotation rate of Late Jurassic continents based on two new igneous rock-based paleomagnetic poles from the La Negra Formation of northern Chile. These poles, based on a total of 46 cooling units, have ages of 165.8 $\pm 1.8 \mathrm{Ma}$ and $152.8 \pm 0.8 \mathrm{Ma}$ based on our Ar-Ar geochronology experiments. By combining these new data with six additional igneous rock-derived paleomagnetic poles from the $165-140 \mathrm{Ma}$ interval, three of which were published or revised after the previous compilations of paleomagnetic data discussed above, we place the strongest constraints to-date on the timing and rate of observed lithospheric rotation in the Late Jurassic Period. We then discuss the implications of this rotation on the occurrence of TPW and its possible geodynamical drivers.

\section{Samples and methods}

\subsection{Geological setting and previous paleomagnetic results}

The La Negra Formation is an extensive succession of Late Jurassic basaltic-andesitic volcanics with up to $1400 \mathrm{~m}$ thickness exposed along the northern coast of Chile between latitudes $22^{\circ} \mathrm{S}$ and $30^{\circ} \mathrm{S}$ (Buchelt and Tellez Cancino, 1988). It is one of several volcanic units of similar composition emplaced along the South American margin during the Jurassic Period referred to locally as the Camaraca, Oficina Viz, and Nacientes del Biobío Formations (SERNAGEOMIN, 2003). The isotopic and trace element compositions of the La Negra Formation show evidence for significant crustal contamination, which has been used to argue for emplacement in a backarc basin setting (Buchelt and Tellez Cancino, 1988; Rogers and Hawkesworth, 1989; Pichowiak et al., 1990; Kramer et al., 2005; Lucassen et al., 2006). 
In the Topopilla area, the La Negra Formation is composed of successive lava flows of between 1 and $5 \mathrm{~m}$ thickness. In a transect of 102 flows, we observed only a single $<10 \mathrm{~cm}$ thick horizon of intercalated, fine-grained sedimentary rock at locality $C$ (see below). The rarity of sedimentary deposits and the lack of observed pillow structures imply that lava emplacement was nearly wholly sub-aerial. Compared to the La Negra Formation at its type locality near Antofagasta, exposures in the Tocopilla region have experienced weaker post-emplacement deformation, showing uniform bedding with low eastward dips in the $10-25^{\circ}$ range. This tilting may be associated with the formation of the Bolivian Orocline, which affected the western margin of South America between approximately $15^{\circ} \mathrm{S}$ and $30^{\circ} \mathrm{S}$ throughout the Paleogene and Neogene (Rousse et al., 2002; Arriagada et al., 2008). Previous paleomagnetic studies of Jurassic to Neogene age rocks throughout these regions have demonstrated that the coastal volcanic units in the Antofagasta-Tocopilla area display no resolvable rotations relative to cratonic South America, although with significant uncertainty due to large observed paleosecular variations [net rotation of $2.2^{\circ}$ $\pm 6.2^{\circ}$ west; Arriagada et al., 2003]. Based on the lack of rotations observed in a $>150 \mathrm{~km}$ segment of the coast between Antofagasta and Tocopilla and the uniformly shallow dip of La Negra flows near Tocopilla, we conclude that our sampling localities are unlikely to have been affected significantly by vertical axis rotations.

One previous paleomagnetic study of the La Negra volcanics by Goguitchaichvili et al. (2003) produced a Jurassic-age paleomagnetic pole based on 280 specimens from 32 successive lava flows (approximate location $22.35^{\circ} \mathrm{S} 70.25^{\circ} \mathrm{W}$ ); these authors subjected samples to alternating field (AF) demagnetization, which revealed samples with both normal and reversed polarities. However, the age of the sampled succession was constrained by only a low precision Rb-Sr age of $187 \pm 13 \mathrm{Ma}$, which is more than 20 My older than any subsequent Ar-Ar age recovered from the La Negra Formation (Rogers and Hawkesworth, 1989; Oliveros et al., 2006). Furthermore, our thermal demagnetization data consistently revealed present-day viscous remanent magnetization (VRM) overprints that are routinely stronger than any high temperature magnetization. Therefore, we consider the application of thermal demagnetization, which is more effective than AF treatment in the removal of VRM, to be vital for the analysis of these samples.

\subsection{Paleomagnetic experiments}

We sampled exposures of La Negra Formation lava flows at five localities designated A-E (Fig. 1). Localities A and B sample the base and top, respectively, of a single $>1 \mathrm{~km}$ thick, continuous section of lava flows located $5 \mathrm{~km}$ south of Tocopilla. Similarly, locality D is located $4 \mathrm{~km}$ inland from locality E and samples stratigraphically higher lava flows of the same continuous section. Locality $\mathrm{C}$ is situated on the coast $\sim 4 \mathrm{~km}$ north of locality E and is separated from localities $\mathrm{D}$ and $\mathrm{E}$ by a dextral strike-slip fault of $\sim 10 \mathrm{~km}$ mapped length (Medina, 2012).

At each locality, we collected between 4 and 6 oriented samples from each lava flow in a continuous transect. At localities A, $\mathrm{B}, \mathrm{D}$, and $\mathrm{E}$, we drilled $2.5 \mathrm{~cm}$ diameter cores oriented using a magnetic compass. We also oriented one core in each flow using a sun compass, which showed the lack of orientation biases due to local magnetic fields. At locality $\mathrm{C}$, we collected between two and three oriented block samples from each flow. Each block sample then yielded between one and four $2.5 \mathrm{~cm}$ diameter cores. In total, our sampling campaign resulted in 503 oriented specimens from 102 lava flows.

We subjected all samples to stepwise thermal demagnetization up to $585^{\circ} \mathrm{C}$ to $700^{\circ} \mathrm{C}$ in $18-20$ steps with spacing between $10^{\circ} \mathrm{C}$ and $40^{\circ} \mathrm{C}$. The magnetic moment of each sample was measured using a 2G Enterprises model 760 superconducting rock magne-

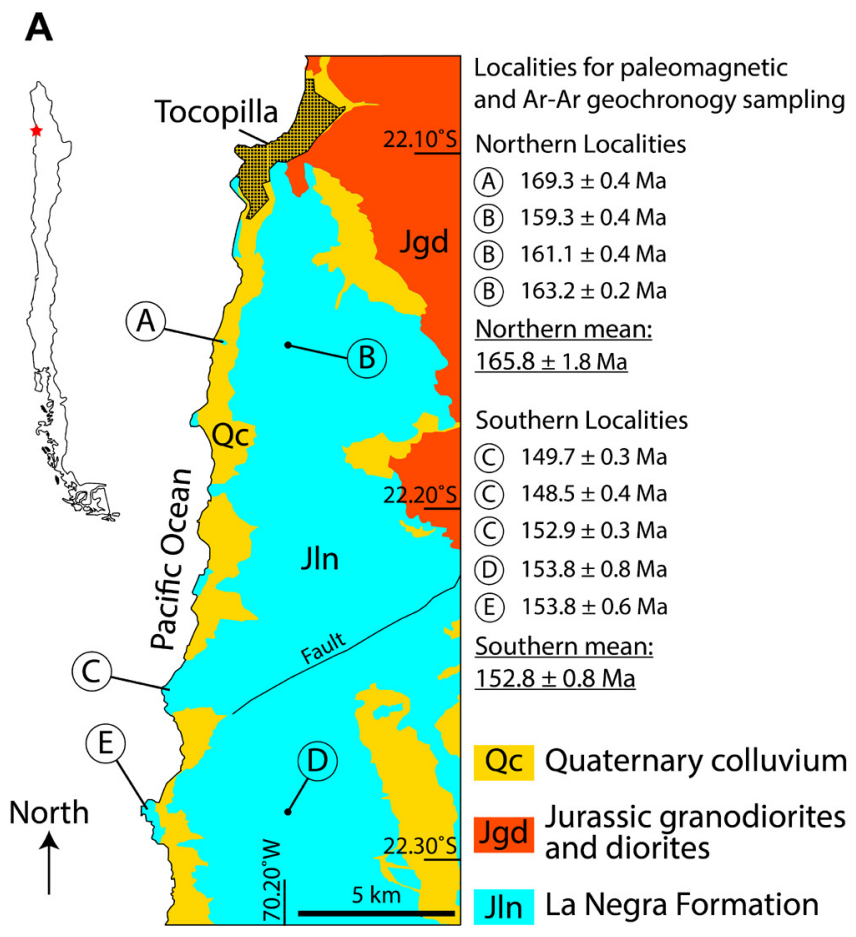

B

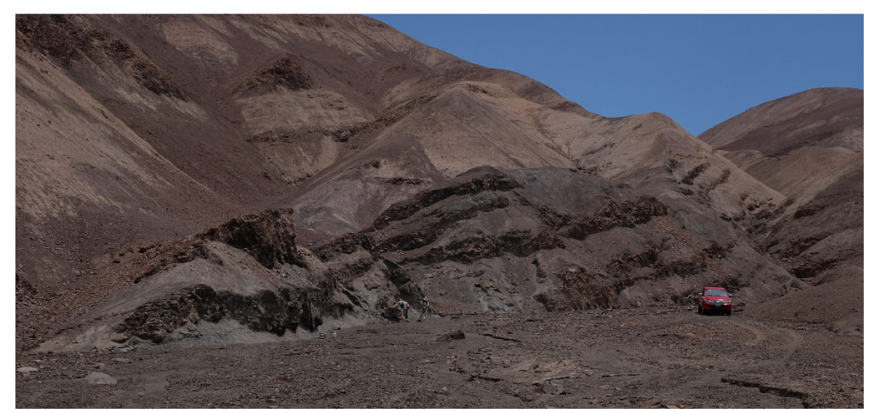

Fig. 1. (A) Simplified geological map of our sampling area near Tocopilla. Location of Tocopilla is denoted by red star in the outline of Chile. (B) Outcrop of multiple La Negra Formation lava flows at locality B showing characteristic $\sim 3 \mathrm{~m}$ scale thickness and shallow eastward dip. (For interpretation of the colors in the figure(s), the reader is referred to the web version of this article.)

tometer (SRM) at the Lamont-Doherty Earth Observatory (LDEO) or a 2G Enterprises model 755 SRM at Harvard University. The large majority of specimens were fully demagnetized by $585^{\circ} \mathrm{C}$. We then extracted component directions from the demagnetization data using principal component analysis (Kirschvink, 1980).

\subsection{Ar-Ar geochronology experiments}

Previous radiometric ages of the La Negra volcanics in the Tocopilla area include Ar-Ar plateau ages between $155.6 \pm 1.4$ and $164.9 \pm 1.7 \mathrm{Ma}$, the latter of which was taken from our paleomagnetic locality A (Oliveros et al., 2006). In the same previous study, a low quality plateau age of $160.1 \pm 1.5$ Ma was also derived from $<1 \mathrm{~km}$ south of our locality $B$, which is consistent with its stratigraphic position above locality A. To refine these previous results and to provide radiometric ages for each of our paleomagnetic sampling localities, we allocated between two and four $2.5 \mathrm{~cm}$ core samples from each locality for mineral separation using a SelFrag@ electric pulse disaggregation system. We then isolated groundmass and plagioclase samples from each core sample and subjected them to neutron irradiation and step-wise laser heating at the LDEO Argon Laboratory. 

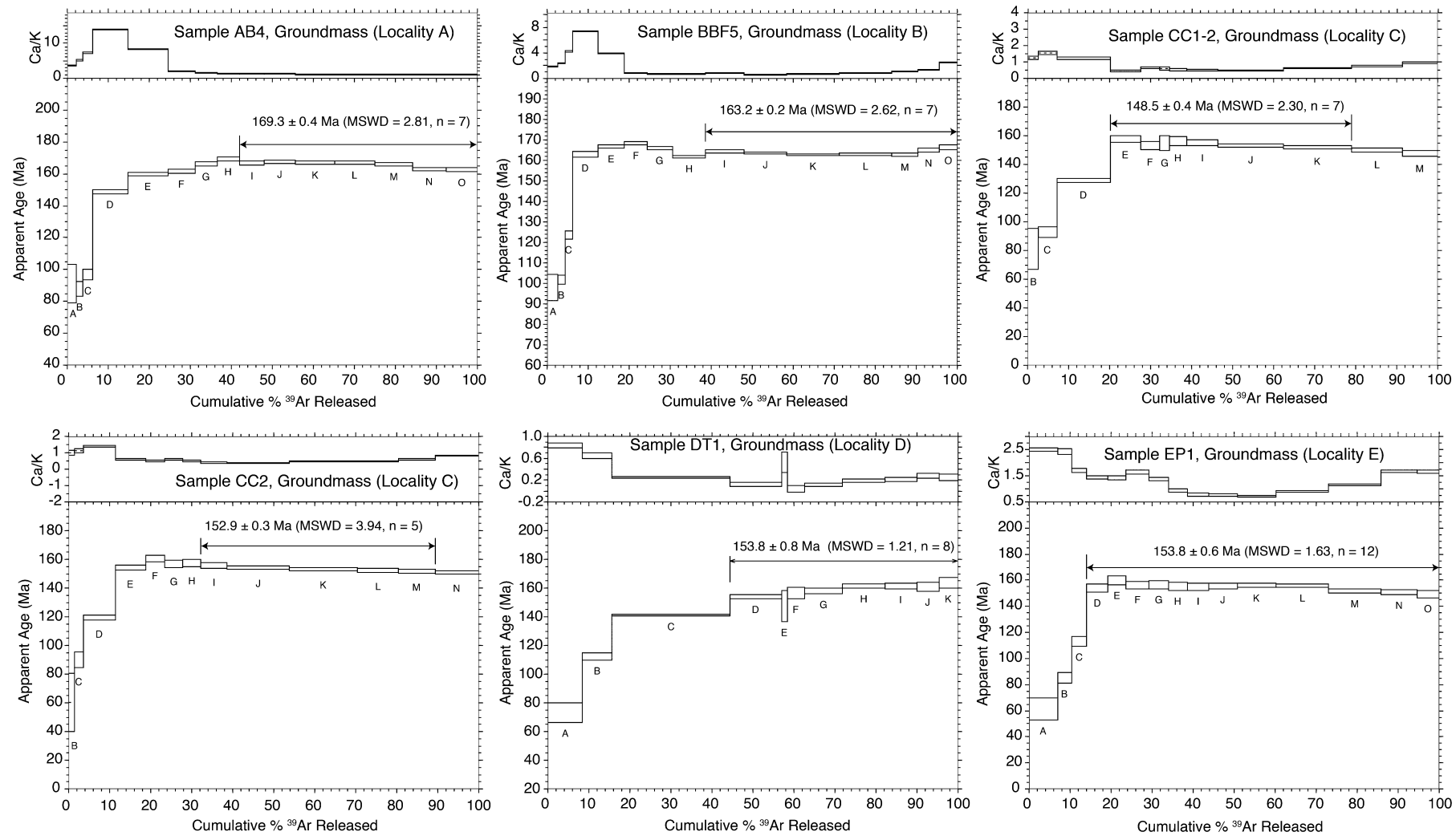

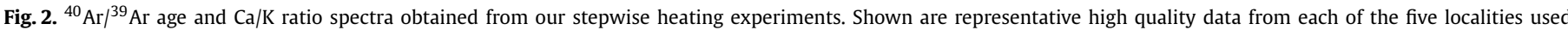
to obtain locality level mean ages. See Table 1 and Supplemental Materials for summary of all geochronology results and raw isotopic composition measurements.

Table 1

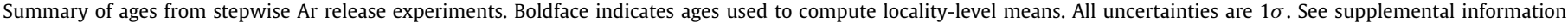
for detailed table of measured Ar isotopic compositions.

\begin{tabular}{|c|c|c|c|c|c|c|c|c|c|c|c|}
\hline Locality & Sample & Latitude & Longitude & $\begin{array}{l}\text { Integrated age } \\
(\mathrm{Ma})\end{array}$ & $\begin{array}{l}\text { Plateau age; } \\
\text { Atmospheric initial } \\
\text { Ar composition } \\
\text { (Ma) }\end{array}$ & $\begin{array}{l}\text { Isochron age } \\
\text { (Ma) }\end{array}$ & $\begin{array}{l}\text { Isochron-derived } \\
{ }^{40} \mathrm{Ar} /{ }^{36} \mathrm{Ar} \text { initial }\end{array}$ & $\begin{array}{l}\text { Plateau age; } \\
\text { Isochron initial } \\
\text { Ar correction } \\
\text { (Ma) }\end{array}$ & $\begin{array}{l}\text { Steps in } \\
\text { plateau }\end{array}$ & $\begin{array}{l}\% \text { Ar in } \\
\text { plateau }\end{array}$ & MSWD \\
\hline A & AB4 & $22.1508^{\circ} \mathrm{S}$ & $70.2186^{\circ} \mathrm{W}$ & $158.9 \pm 0.7$ & $165.7 \pm 0.4$ & $169.2 \pm 1.9$ & $257 \pm 11$ & $169.3 \pm 0.4$ & 7 & 58 & 2.81 \\
\hline A & A2 & $22.1500^{\circ} \mathrm{S}$ & $70.2211^{\circ} \mathrm{W}$ & $150.5 \pm 0.7$ & $152.4 \pm 0.5$ & $155 \pm 8$ & $280 \pm 90$ & $153.7 \pm 0.5$ & 8 & 69 & 1.20 \\
\hline B & BA3 & $22.1546^{\circ} \mathrm{S}$ & $70.1990^{\circ} \mathrm{W}$ & $156.5 \pm 1.0$ & $160.1 \pm 0.4$ & $159 \pm 3$ & $300 \pm 20$ & $159.3 \pm 0.4$ & 9 & 70 & 1.25 \\
\hline B & BA4 & $22.1546^{\circ} \mathrm{S}$ & $70.1990^{\circ} \mathrm{W}$ & $155.3 \pm 0.9$ & $160.7 \pm 0.4$ & 159. \pm 4 & $290 \pm 30$ & $161.1 \pm 0.4$ & 8 & 58 & 2.07 \\
\hline B & BA5 & $22.1546^{\circ} \mathrm{S}$ & $70.1990^{\circ} \mathrm{W}$ & $154.6 \pm 0.7$ & $160.0 \pm 0.4$ & $153 \pm 10$ & $360 \pm 80$ & None & $\mathrm{N} / \mathrm{A}$ & $\mathrm{N} / \mathrm{A}$ & $\mathrm{N} / \mathrm{A}$ \\
\hline B & BBF5 & $22.1490^{\circ} \mathrm{S}$ & $70.1917^{\circ} \mathrm{W}$ & $160.3 \pm 0.6$ & $163.4 \pm 0.2$ & $164 \pm 2$ & $300 \pm 16$ & $163.2 \pm 0.2$ & 7 & 62 & 2.62 \\
\hline C & CC1-1 & $22.2351^{\circ} \mathrm{S}$ & $70.2270^{\circ} \mathrm{W}$ & $140.9 \pm 1.4$ & None & $148 \pm 2$ & $285 \pm 11$ & $149.7 \pm 0.3$ & 9 & 58 & 2.14 \\
\hline C & $\mathrm{CC} 1-2$ & $22.2351^{\circ} \mathrm{S}$ & $70.2270^{\circ} \mathrm{W}$ & $144.8 \pm 0.9$ & $152.9 \pm 0.4$ & $147 \pm 5$ & $340 \pm 40$ & $148.5 \pm 0.4$ & 7 & 59 & 2.30 \\
\hline C & $\mathrm{CC} 2$ & $22.2351^{\circ} \mathrm{S}$ & $70.2270^{\circ} \mathrm{W}$ & $141.0 \pm 0.6$ & $148.6 \pm 0.3$ & $146 \pm 4$ & $290 \pm 30$ & $152.9 \pm 0.3$ & 5 & 57 & 3.94 \\
\hline $\mathrm{D}$ & DT1 & $22.2904^{\circ} \mathrm{S}$ & $70.1941^{\circ} \mathrm{W}$ & $142.9 \pm 1.0$ & None & $155 \pm 7$ & $350 \pm 80$ & $153.8 \pm 0.8$ & 8 & 56 & 1.21 \\
\hline $\mathrm{D}$ & DA3 & $22.2935^{\circ} \mathrm{S}$ & $70.1998^{\circ} \mathrm{W}$ & $145.2 \pm 0.6$ & None & $158 \pm 2$ & $258 \pm 8$ & None & $\mathrm{N} / \mathrm{A}$ & $\mathrm{N} / \mathrm{A}$ & $\mathrm{N} / \mathrm{A}$ \\
\hline $\mathrm{E}$ & ED5 & $22.2842^{\circ} \mathrm{S}$ & $70.2462^{\circ} \mathrm{W}$ & $136.1 \pm 1.1$ & None & $156 \pm 14$ & $260 \pm 70$ & None & $\mathrm{N} / \mathrm{A}$ & $\mathrm{N} / \mathrm{A}$ & $\mathrm{N} / \mathrm{A}$ \\
\hline $\mathrm{E}$ & EP1 & $22.2838^{\circ} \mathrm{S}$ & $70.2431^{\circ} \mathrm{W}$ & $143.8 \pm 1.4$ & $154.0 \pm 0.6$ & $154 \pm 3$ & $300 \pm 20$ & $153.8 \pm 0.6$ & 12 & 86 & 1.63 \\
\hline
\end{tabular}

Samples were co-irradiated with Fish Canyon sanidine, [28.201 Ma; Kuiper et al., 2008] at the USGS TRIGA reactor in Denver for 8 h. Samples were loaded into tantalum tubes, then into 5 pit planchets, and incrementally heated using a PhotonMachines diode laser. Low temperature steps for all of the samples were finished prior to high temperature steps. Following a 10 min cleanup with ST101 getters at 2 A, gas was introduced into a VG5400 noble gas mass spectrometer and isotopes were measured by peak hopping on an analogue multiplier system. Blanks were analyzed every four unknown analyses and air pipettes $\left(\sim 4 \times 10^{-14} \mathrm{~mol}\right)$ were analyzed every twelve unknown analyses (bracketed by blanks). Atmospheric ${ }^{40} \mathrm{Ar} /{ }^{36} \mathrm{Ar}$ corrections were made using the time series of these blanks and airs. The measured ${ }^{40} \mathrm{Ar} /{ }^{36} \mathrm{Ar}$ for the air pipettes during the interval of these analyses was $279.64 \pm 3.01$ for measurements on locality C samples and $281.46 \pm 1.47$ for all others.
These corrections were made to the published value of 298.6 following Lee et al. (2006). Corrections for nuclear interferences were based on Dalrymple et al. (1981). All raw geochronological data are available in the supplementary materials.

\section{Results}

The Ar-Ar ages derived from our stepwise degassing experiments are given in Fig. 2 and Table 1. The full collection of data is available in the supplement. Due to disturbance in the low temperature Ar releases, possibly related to Cretaceous age intrusives, we only consider well-defined plateau ages that contain more than $50 \%$ of the released ${ }^{39} \mathrm{Ar}$ and consist of at least three consecutive heating steps with mutually indistinguishable ${ }^{40} \mathrm{Ar} /{ }^{39} \mathrm{Ar}$ ages. Further, although we conducted stepwise heating experiments on both 
Table 2

Weighted mean Ar-Ar ages and $1 \sigma$ uncertainty for each locality and locality group based on the ages listed in Table 2. Uncertainties for the locality groups were approximated by assuming that the full range of locality ages in the group is equal to $2 \sigma$.

\begin{tabular}{ll}
\hline Locality & $\begin{array}{l}\text { Weighted mean age } \\
(\mathrm{Ma})\end{array}$ \\
\hline A & $169.3 \pm 0.4$ \\
B & $162.2 \pm 0.2$ \\
C & $150.7 \pm 0.2$ \\
D & $153.8 \pm 0.8$ \\
E & $153.8 \pm 0.6$ \\
A-B & $165.8 \pm 1.8$ \\
C-E & $152.8 \pm 0.8$ \\
\hline
\end{tabular}

groundmass and plagioclases separates, many plagioclase-based ${ }^{40} \mathrm{Ar} /{ }^{39} \mathrm{Ar}$ release spectra show anomalous shapes with computed ages $\geq 170$ Ma for low temperature steps (see supplementary materials). Such old ages are inconsistent with groundmass results and biostratigraphical constraints (Kramer et al., 2005). We therefore focus our further analyses on groundmass samples.

Applying these quality criteria and a correction for the initial Ar composition based on isochron results, we find that one sample from each locality A, D and E and three samples each from locality $B$ and $C$ yielded acceptable ages (Tables 1-2). Although sample A2 produced a plateau age, its much younger value $(153.7 \pm 0.5 \mathrm{Ma})$ is inconsistent with the lower stratigraphic location of locality A compared to locality B. Furthermore, the previously published ArAr plateau age of $164.9 \pm 0.9$ Ma (Oliveros et al., 2006) for locality $A$ is more consistent with the $169.3 \pm 0.4$ Ma age from our AB4 sample. We therefore adopt results from sample $A B 4$ as the best constraints on the age of locality A.

Between the two northern localities $A$ and $B$, the 7.1 My younger age of locality $B$ is consistent with its stratigraphically higher position. Given the $\sim 1450 \mathrm{~m}$ stratigraphic displacement between the age-dated sites in localities $A$ and $B$ and assuming a typical flow thickness of $3 \mathrm{~m}$, we estimate an approximate mean eruption interval of $15 \mathrm{ky}$ per flow.

$\mathrm{Ar}-\mathrm{Ar}$ plateau ages from the three southern localities $\mathrm{C}-\mathrm{E}$ are uniformly younger than those from the northern localities. The indistinguishable ages from localities D and E, which are separated by more than $1 \mathrm{~km}$ of stratigraphy, suggest a more rapid rate of flow emplacement compared to that implied by localities $A$ and $B$. Due to the presence of a fault between locality $C$ and the D-E section (Fig. 1), the relative stratigraphic position of locality $C$ is uncertain and cannot be used to verify the Ar-Ar ages. The small age difference between these localities is consistent with a limited amount of relative motion.

To ensure sufficient data for reliable paleomagnetic poles, we group the data from the northern localities A and B into a single pole with weighted mean age $165.8 \pm 1.8 \mathrm{Ma}$ and localities C-E into another dataset with weighted mean age $152.8 \pm 0.8 \mathrm{Ma}$ (Table 2). For these mean ages, we computed approximate $1 \sigma$ uncertainties assuming that the range of locality ages in each group represents a $2 \sigma$ spread.

Our analysis of thermal demagnetization sequences shows that 262 specimens carry a low temperature (LT) component of magnetization generally blocked below $320^{\circ} \mathrm{C}$ with maximum angular deviation (MAD) less than $15^{\circ}$ and encompassing more than 5 demagnetization steps (Figs. 3, S1). Although approximately $10 \%$ of LT components display widely scattered directions, which may be due to contamination from recent lightning strikes, the mean LT direction $\left(D=354.6^{\circ}, I=-35.7^{\circ}, \alpha_{95}=4.0^{\circ}\right)$ is consistent with a recent VRM, which has an expected direction of due north with $-38.9^{\circ}$ inclination.
We found that 414 specimens carry a high temperature (HT) component of magnetization blocked between approximately $300^{\circ} \mathrm{C}$ and $585^{\circ} \mathrm{C}$ (Fig. 3). After excluding HT components with MAD greater than $15^{\circ}$, we computed the site mean direction and precision parameter $k$ for each of 102 cooling units. To exclude data with spurious magnetization directions caused by poor rock magnetic recording fidelity, lightning, or remagnetization, we focused further analysis on the 52 low-scatter sites with at least 3 samples and $k \geq 50$ (Supplementary Table S1).

Two sites in locality B (BA and BE) and three sites in locality D (DH, DI, and DJ) exhibit anomalous directions that, combined with the consecutive stratigraphic locations of these sites, strongly suggest that they record transitional magnetic fields (Fig. 4). In addition, the anomalous direction of site EE and its location between surrounding sites of normal and reversed polarity suggest the occurrence of another transitional geodynamo regime. Together, transitional fields are recorded in $12 \%$ of our sites, which is much higher than the present-day expectation of 1-2 reversals of $\sim 10^{4} \mathrm{y}$ duration per million years (Clement, 2004). However, a high rate of geomagnetic field reversals has been documented in the Late Jurassic (Steiner et al., 1987), which is associated with the Jurassic Quiet Zone identified in marine magnetic surveys (Handschumacher et al., 1988). Reversal frequencies of up to 10 per million years estimated from seafloor magnetic anomalies in the 170-156 Ma interval correspond to a $\sim 10 \%$ probability of capturing transitional directions assuming a $\sim 10^{4}$ y duration for reversals (Tominaga et al., 2008), which is fully consistent with our observations.

To characterize further the stability of the Late Jurassic magnetic field, we quantify the amplitude of paleosecular variation (PSV) by computing the angular standard deviation $\left(S_{\mathrm{B}}\right)$ of virtual geomagnetic poles (VGPs) from our tilt-corrected site means. After obtaining VGPS for each of 52 sites that pass our quality criteria (see above and Table S1) and applying a commonlyadopted cutoff angle of $45^{\circ}$ to exclude transitional site directions, we find $S_{\mathrm{B}}=22.6^{\circ}$. Such a high $S_{\mathrm{B}}$ is nearly a factor of two higher than for the 0-5 Ma lava data (Opdyke et al., 2015; Cromwell et al., 2018) and comparable to the largest documented PSV amplitudes during and subsequent to the Mesozoic (Biggin et al., 2008; Doubrovine et al., 2019). Computing $S_{\mathrm{B}}$ separately for each of the five localities resulted in wide scatter between $15.7^{\circ}$ and $34.6^{\circ}$, suggesting that potentially unaccounted for differential tectonic motion among our sampling localities cannot explain the large scatter. Our data therefore supports previous suggestions that the Late Jurassic, at least in certain intervals, was a time of low dipole field stability (Palmer et al., 1980; Iglesia Llanos et al., 2003; Biggin et al., 2008).

Of the remaining 46 sites that have low within-site scatter and show non-transitional directions, 21 and 25 display normal and reversed polarities, respectively. After gathering tilt-corrected site directions into the $165.8 \mathrm{Ma}$ and $152.8 \mathrm{Ma}$ age groups, we found that the 28 sites of the older group pass a reversal test with confidence classification $C$ [critical angle $\gamma_{\mathrm{c}}=16.4^{\circ}$; observed angle $=15.8^{\circ}$ McFadden and McElhinny, 1990], while the 18 sites of the younger group yield an indeterminate reversal test $\left(\gamma_{c}=29.0\right.$; observed angle $=18.6^{\circ}$ ). Due to the similar, eastward dipping bedding attitudes of all five localities, a formal fold test is not possible. Even so, we observe that the precision parameter $k$ of all passing sites, after conversion to normal polarity, is 8.2 and 8.9 in in-situ and tilt-corrected coordinates, respectively. This is consistent with a pre-folding age of remanence while indicating that the directional scatter among sites is dominated by PSV instead of bedding attitude variations. Based on the presence of normal and reversed polarities, the passed reversal test for the older age group, and the origin-trending nature of the HT component, we conclude that this magnetization represents a primary record of magnetic fields during lava flow emplacement. 

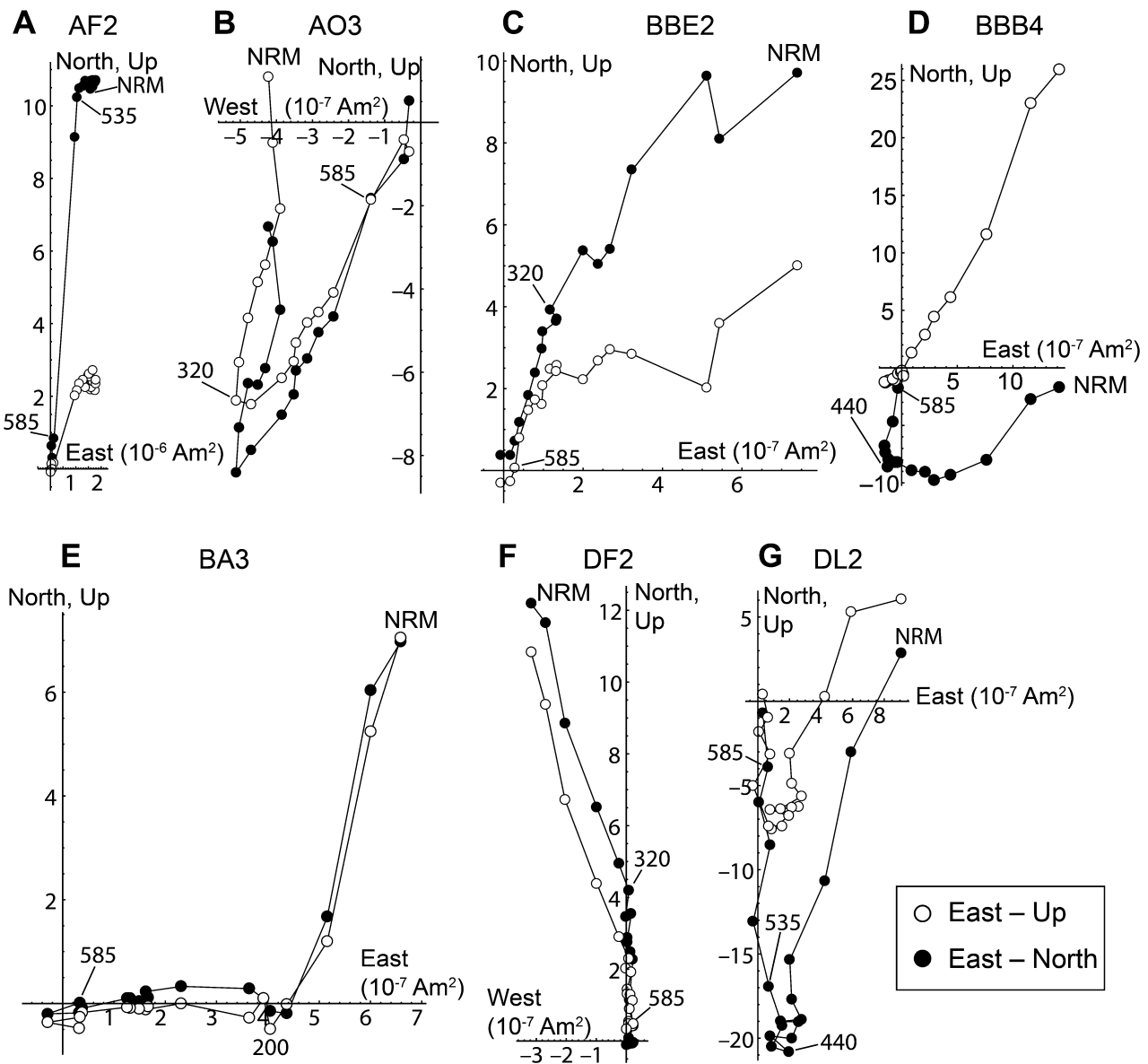

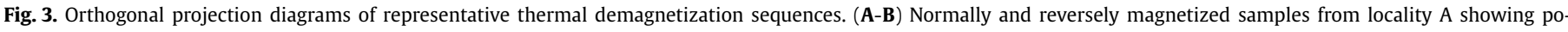

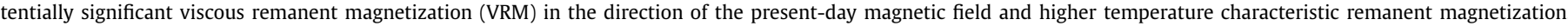

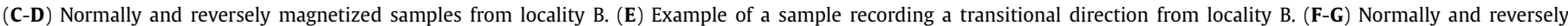

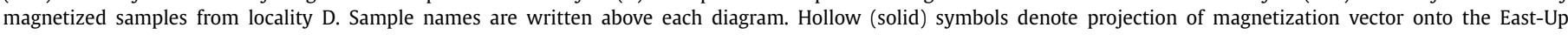
(East-North) plane.

Finally, we computed paleomagnetic poles for 165.8 and 152.8 Ma using HT component directions in tilt-corrected coordinates (Fig. 5; Table 3). We find an $8.9^{\circ}$ displacement between the two poles, which is not distinguishable at the 95\% confidence level. To facilitate comparison with other paleomagnetic poles in the 170-140 Ma time interval, we rotated our paleomagnetic poles into a South African reference frame. Due to uncertainty in the relative paleogeographic position of South America with respect to Africa, especially regarding the partitioning of intraplate deformation within both continents (Eagles, 2007; Nürnberg and Müller, 1991; Torsvik et al., 2009), multiple Euler rotations have been proposed to map between South American and South African coordinates (Lottes and Rowley, 1990; Nürnberg and Müller, 1991; König and Jokat, 2006; Eagles, 2007; Torsvik et al., 2008, 2009). To quantify the effect of the chosen South America-South Africa reconstruction on the resulting global APW path, we computed our poles in South African coordinates using the rotation parameters of both Lottes and Rowley (1990) and Torsvik et al. (2008), which are representative of models that incorporate low and significant levels of intra-plate displacements within South America, respectively (Table 3).

\section{Discussion}

\subsection{Net continental rotation in the Late Jurassic}

We combine our computed paleomagnetic poles at 165.8 and 152.8 Ma with existing high-fidelity poles to derive the rate of net continental motion during the Jurassic Period. We include only well-dated, igneous rock-derived paleomagnetic poles in the 200-140 Ma interval and translate them into South African coordinates using the finite rotation parameters of Torsvik et al. (2008), which applies a $3^{\circ}$ intra-plate rotation between Patagonia and cratonic South America (Fig. 5). For poles between 200 and $170 \mathrm{Ma}$, we adopt the compilation of Kent and Irving (2010), which excludes sedimentary rock-based poles due to the potential for inclination error (Kent and Tauxe, 2005). Similarly for the 170-140 Ma interval, we begin with the igneous pole compilation of Kent and Irving (2010), which excludes poles from the Colorado Plateau due to the possibility of vertical axis rotations. We modify this compilation by adding five new or revised igneous poles published after 2010. We also initially exclude the poles from the Moat Volcanics, Prospect Dolerite, Hinlopenstretet intrusives due to geochronological uncertainties (see below and Supplementary Materials). We retain three poles derived from kimberlites in both South Africa and North America despite the small number of sites samples (Van Fossen and Kent, 1993; Hargraves et al., 1997; Kent et al., 2015). Based on our simulations of PSV sampling, the observation of highly concordant normal and reversed polarity magnetizations in the North American kimberlites strongly suggests that the directions adequately average PSV (see Supplementary Materials). In the case of the South African kimberlites, the presence of normal and reverse polarities in sub-equal proportions suggests sampling of the geomagnetic field at distinct times (Hargraves, 1989). Our simulations that the availability of six dis- 


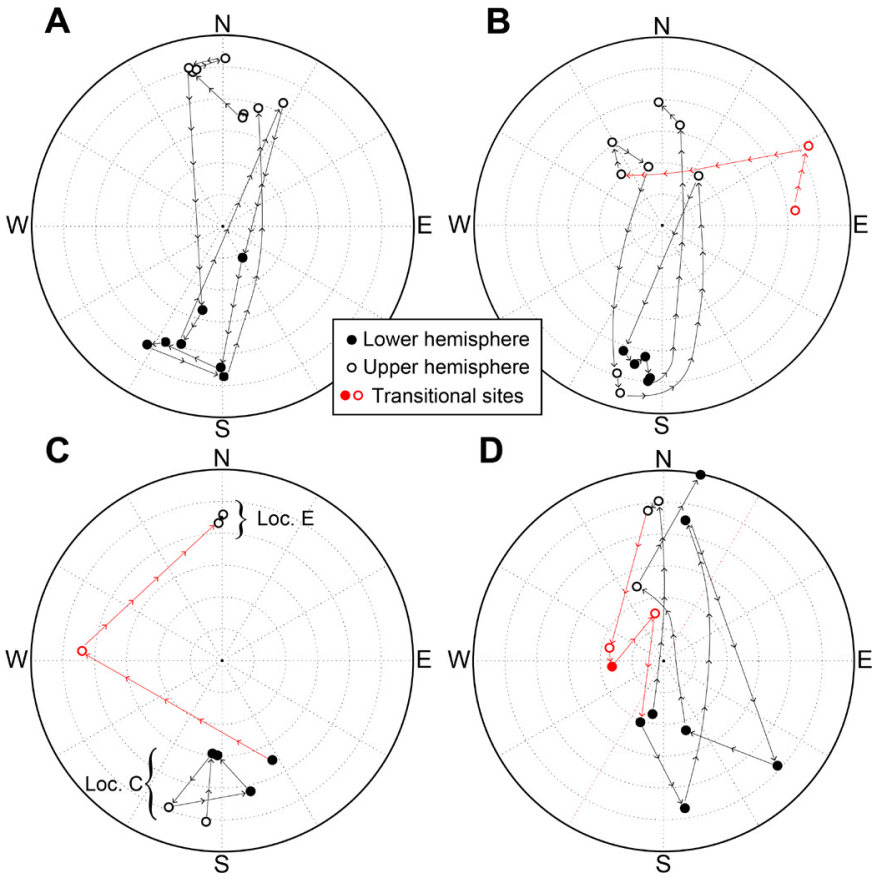

Fig. 4. Equal area stereonet diagrams showing mean tilt-corrected directions of 52 sites with low within-site scatter. Panels show sites from the five different localities (A) locality A, (B) locality B, (C) locality C and E, and (D) locality D. Lines with arrows show the stratigraphic progression of sites from down-section to up-section. Red directions denote to transitional sites that were not used to compute the paleomagnetic pole.

tinct sites permits accurate estimation of the mean geomagnetic field direction with a total $\alpha_{95}$ of $10.3^{\circ}$ (Table 3; Supplementary Materials). These modifications result in a total of eight poles in our compilation for the 170-145 Ma interval. We then group all

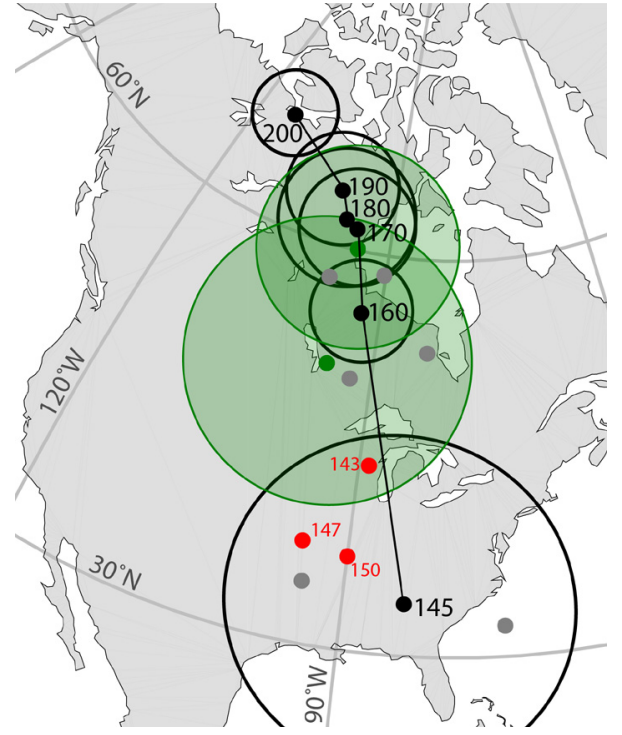

Fig. 5. Composite running mean poles (black), La Negra volcanics poles (green), and seven other igneous rock-derived poles from the 170-140 Ma interval (gray) plotted in the South African coordinate system. Running means were computed from paleomagnetic poles within \pm 10 My of the indicated age. Mean poles from the 200-170 Ma interval are computed from the compilation by Kent and Irving (2010). Red points indicate inclination shallowing-corrected poles from Adria (Muttoni and Kent, 2019). Poles used to compute 170-145 Ma averages are given in Table 3. Circles denote the $95 \%$ confidence interval.

poles in bins of 20 My width, resulting in composite poles for $200,190,180,170$, and 160 Ma. Due to the ages of available data, we compute a nominal 145 Ma mean pole using the 146.0 and 146.4 Ma kimberlite poles from South Africa and North America, respectively (Table 4). Although this last composite igneous pole consists of only two paleomagnetic data points, inclination

Table 3

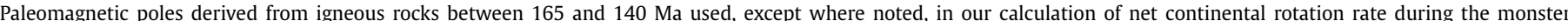

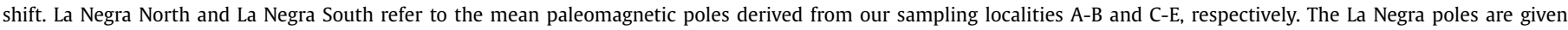

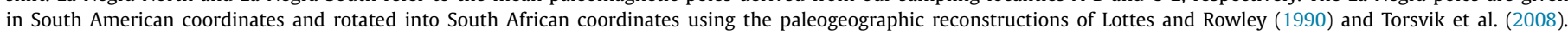
The remaining seven previously published poles are rotated into South African coordinates using the parameters of Torsvik et al. (2008).

\begin{tabular}{|c|c|c|c|c|c|c|}
\hline Pole name & $\begin{array}{l}\text { Age } \\
(\mathrm{Ma})\end{array}$ & $N$ & $\begin{array}{l}\text { Pole Lat. } \\
\left({ }^{\circ} \mathrm{N}\right)\end{array}$ & $\begin{array}{l}\text { Pole Long. } \\
\left({ }^{\circ} \mathrm{E}\right)\end{array}$ & $\begin{array}{l}\text { Pole } \alpha_{95} \\
\left(^{\circ}\right)\end{array}$ & Reference \\
\hline \multicolumn{7}{|c|}{ South American Coordinates } \\
\hline La Negra North & $165.8 \pm 1.8$ & 28 & 84.3 & 0.9 & 7.6 & This work \\
\hline La Negra South & $152.8 \pm 0.8$ & 18 & 84.5 & 256.4 & 10.8 & This work \\
\hline \multicolumn{7}{|c|}{$\begin{array}{l}\text { South African Coordinates } \\
\text { (Lottes and Rowley, 1990) }\end{array}$} \\
\hline La Negra North & $165.8 \pm 1.8$ & 28 & 57.0 & 267.0 & 7.6 & This work \\
\hline La Negra South & $152.8 \pm 0.8$ & 18 & 48.2 & 265.7 & 10.8 & This work \\
\hline \multicolumn{7}{|c|}{$\begin{array}{l}\text { South African Coordinates } \\
\text { (Torsvik et al., 2008) }\end{array}$} \\
\hline La Negra North & $165.8 \pm 1.8$ & 28 & 59.9 & 265.8 & 7.6 & This work \\
\hline La Negra South & $152.8 \pm 0.8$ & 18 & 51.1 & 265.0 & 10.8 & This work \\
\hline Moat ${ }^{*}$ & $169+$ & & 63.6 & 287.7 & & Van Fossen and Kent (1990) \\
\hline Prospect ${ }^{*}$ & 168 & & 62.0 & 258.5 & & Schmidt (1982) \\
\hline El Quemado & $156.5 \pm 1.9$ & 16 & 58.3 & 270.3 & 8.0 & Iglesia Llanos et al. (2003) \\
\hline Chon Aike & $155 \pm 3.5$ & 23 & 57.4 & 262.8 & 8.6 & Ruiz González et al. (2019) \\
\hline Peddie & $154.9 \pm 1.1$ & 19 & 50.3 & 268.0 & 3.7 & Kent et al. (2015) \\
\hline Triple B & $157.5 \pm 1.2$ & 15 & 52.8 & 276.9 & 4.1 & Kent et al. (2015) \\
\hline Swartruggens-Bumbeni & $146.0 \pm 1$ & 6 & 31.7 & $284.3^{* * *}$ & $10.3(6.3)^{* *}$ & Hargraves et al. (1997) \\
\hline Hinlopenstretet & $144 \pm 5$ & 17 & 38.1 & 260.8 & 7.5 & Halvorsen (1989) \\
\hline Ithaca & $146.4 \pm 1.6$ & 7 & 34.6 & 266.6 & 3.8 & Van Fossen and Kent (1993) \\
\hline & & & & & & Kent et al. (2015) \\
\hline
\end{tabular}

* Not included reference means; see text and supplementary materials.

** Study provided $\alpha_{95}=6.3^{\circ}$. Larger $10.3^{\circ}$ value accounts for the small number of sites (six). See text and Supplementary Materials.

${ }^{* * *}$ Note that $273.3^{\circ}$ was erroneously tabulated in Kent and Irving (2010). 
Table 4

Composite poles in South Africa coordinates. Individual paleomagnetic poles for the 200-170 Ma composites were based on Kent and Irving (2010) while those for the 160 and 145 Ma composites are listed in Table 3.

\begin{tabular}{llllll}
\hline $\begin{array}{l}\text { Nominal age } \\
(\mathrm{Ma})\end{array}$ & Mean age & $\begin{array}{l}\text { Number of } \\
\text { poles }\end{array}$ & $\begin{array}{l}\text { Pole position } \\
\text { (Lat. N, Long. E) }\end{array}$ & $k$ & $\alpha_{95}$ \\
\hline 200 & 200.0 & 14 & $69.7^{\circ} 244.0^{\circ}$ & 128.3 & $3.3^{\circ}$ \\
190 & 188.4 & 18 & $66.7^{\circ} 258.7^{\circ}$ & 55.6 & $4.4^{\circ}$ \\
180 & 183.6 & 13 & $64.0^{\circ} 263.5^{\circ}$ & 70.2 & $4.6^{\circ}$ \\
170 & 172.4 & 2 & $63.2^{\circ} 264.7^{\circ}$ & 296.4 & $5.8^{\circ}$ \\
160 & 157.1 & 6 & $55.0^{\circ} 268.2^{\circ}$ & 262.3 & $3.5^{\circ}$ \\
145 & 146.2 & 2 & $33.5^{\circ} 275.6^{\circ}$ & 46.8 & $13.0^{\circ}$ \\
\hline
\end{tabular}

shallowing-corrected sedimentary poles from Adria strongly corroborate its position (Muttoni and Kent, 2019).

To understand the uncertainties introduced by the choice of paleogeographic reconstructions on our APW path, we compute the rate of apparent polar motion between 170 and 145 Ma using different plate models for the Late Jurassic. We account for the uncertainty in both age and paleopole position for all nine igneous paleomagnetic poles by assuming an $1 \sigma$ age uncertainty of \pm 2.5 My for each composite pole and using a Monte Carlo resampling algorithm to generate $10^{4}$ synthetic APW paths. We then compute the APW velocity along the best-fit great circle and its uncertainty from these synthetic datasets. We find that our reference pole compilation, which uses the paleogeographic reconstructions of Torsvik et al. (2008), implies an APW rate of $1.21^{\circ} \pm 0.34^{\circ} \mathrm{My}^{-1}$ $(1 \sigma)$ between 170 and $145 \mathrm{Ma}$ (Figs. 5, 6). Recomputing our compiled poles in South African coordinates using the reconstruction of Lottes and Rowley (1990), which does not include intra-plate displacements in South America, yields an indistinguishable APW rate of $1.15^{\circ} \pm 0.36^{\circ} \mathrm{My}^{-1}$ during the same time interval. We therefore conclude that the choice of continental reconstruction has a negligible effect on the composite APW path.

Next, we test the effect of excluding or including specific paleomagnetic poles. Among our five poles in the 153-158 Ma interval (Table 3), the Patagonian Chon Aike and El Quemado Formation poles may be affected by intra-plate deformation not accounted for in our adopted continental reconstructions [e.g., König and Jokat, 2006]. We find that our 170-145 Ma APW path without the Patagonian poles corresponds to a slightly slower rotation rate of $1.20^{\circ}$ $\pm 0.34^{\circ} \mathrm{My}^{-1}$. Testing the sensitivity of our results to the inclusion of additional paleomagnetic poles, retaining poles from the poorly dated (see supplementary materials) Moat Volcanics ( $\sim 169 \mathrm{Ma})$ and Prospect Dolerite $(\sim 168 \mathrm{Ma})$ changes our derived rotation rate to $1.24^{\circ} \pm 0.35^{\circ} \mathrm{My}^{-1}$. All of the above rates are mutually indistinguishable, implying that our composite APW path is robust with respect to assumed paleogeography and the choice of the most reliable igneous rock-derived paleomagnetic poles.

After establishing a reliable composite APW path in South Africa coordinates, we compute the net rotation of all major continental plates following the methodology of Torsvik et al. (2010). First, we separately quantify the motion of Gondwana and Laurasia as Euler rotations. For Gondwana we fit our composite APW path in South African coordinates to small circle rotations while for Laurentia we also incorporate North Atlantic spreading velocities based on the plate reconstructions of Torsvik et al. (2008). We then integrate the angular velocity vector of surface elements within continental land areas using continental shape models from Seton et al. (2012). We exclude the United China Block from our analysis due to the lack of reliable reconstructions owing to the lack of surviving, well-dated marine magnetic anomalies linking it to other continents (Cogné et al., 2005; Van der Voo et al., 2015).

The resulting mean net continental rotation rate between 170 and $145 \mathrm{Ma}$ is $1.21^{\circ} \pm 0.35 \mathrm{My}^{-1}$ around an Euler pole at $29.3^{\circ} \mathrm{N}$ $7.1^{\circ} \mathrm{W}$, where the $1 \sigma$ uncertainty is derived from both age and location uncertainty of the 170 and 145 Ma composite poles (see above; Fig. 6). Between 160 and $145 \mathrm{Ma}$, we find that net continental rotation occurred at a higher rate of $1.46^{\circ} \pm 0.65^{\circ} \mathrm{My}^{-1}$ around a similar axis. The corresponding total amplitude of net continental rotation between 170 and $145 \mathrm{Ma}$, computed by tracking the motion of an equatorial point separated from the net rotation Euler pole by $90^{\circ}$ of longitude, is $25.3^{\circ} \pm 7.3^{\circ}$. This net rotation amplitude is comparable to that derived from a succession of inclination shallowing-corrected poles from Adria (Muttoni and Kent, 2019), although our computed rates are generally slower due to the use of $170 \mathrm{Ma}$ as the anchor point for the initiation of the rotation.

The above computed values for the mean or peak net continental rotation rate between 170 and $145 \mathrm{Ma}$ are statistically distinguishable from a net continental rotation rate of $0.07^{\circ} \pm 0.04^{\circ}$ $\mathrm{My}^{-1}$ we compute for the 200-170 Ma interval, indicating that the net continental rotation rate of the Earth underwent a significant acceleration by $\sim 160 \mathrm{Ma}$ and possibly by $\sim 170 \mathrm{Ma}$ (Fig. 6 ).

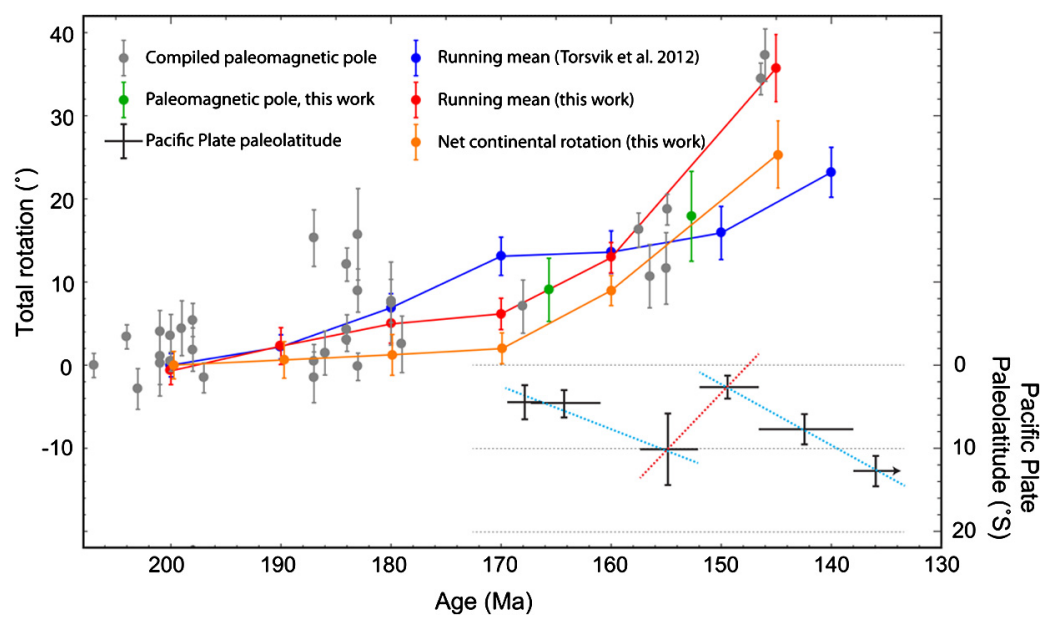

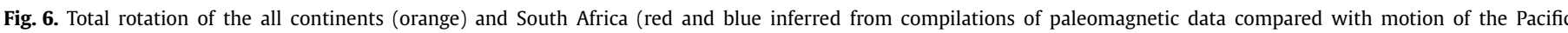

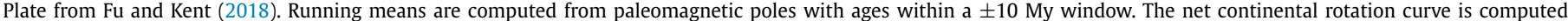

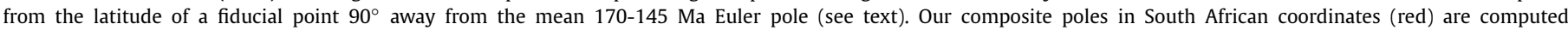

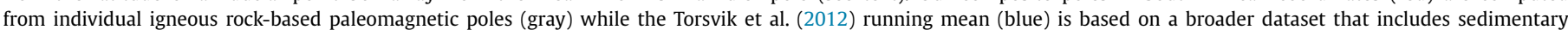

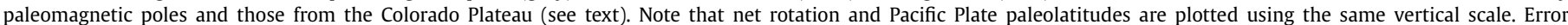
bars show $1 \sigma$ uncertainties. 


\subsection{Implications for Late Jurassic TPW}

Our new 165.8 and 152.8 Ma paleomagnetic poles, combined with previous studies (Table 3), provide strong evidence that the Late Jurassic monster shift consisted of a net continental rotation of $25.3^{\circ} \pm 7.3^{\circ}$ with a peak rate of $1.46^{\circ} \pm 0.65^{\circ} \mathrm{My}^{-1}$. Available igneous rock-derived paleomagnetic poles constrain the duration of this rotation to between at least 155 and $145 \mathrm{Ma}$, although due to the lack of high reliability igneous poles between $\sim 180$ and 165.8 Ma [see Supplementary Materials; Kent and Irving, 2010], the initiation of the shift may have occurred as early as 170 to 175 Ma (Fig. 5). Meanwhile, 130-140 Ma paleomagnetic poles derived from igneous rocks in South America and Africa suggest that the rotation had ceased or reversed direction by $\sim 140$ Ma (Kent and Irving, 2010).

Our net continental rotation computations shows that Laurasia and Gondwana, which accounted for approximately one-third of the Earth's surface area during the Late Jurassic (Seton et al., 2012), participated in the monster shift event. Direct constraints on the motion of the remaining two-thirds of the Earth surface, which consisted predominantly of the oceanic plates of the Pacific Basin, are scarce due to the small area of Jurassic-age Pacific Plate that is presently preserved. Paleomagnetic data taken from the Ocean Drilling Program (ODP) core 801B show that the Pacific Plate underwent steady southward drift during the Late Jurassic through Early Cretaceous except for a brief interval between $\sim 157$ and $147 \mathrm{Ma}$, although depositional hiatuses permit an early initiation of motion at $\sim 161$ Ma (Larson et al., 1992; $\mathrm{Fu}$ and Kent, 2018). During this time of anomalous motion, the Pacific Plate underwent northward drift with a velocity of $1.45^{\circ}$ $\pm 0.76^{\circ} \mathrm{My}^{-1}$, which is in close agreement with the expected northward drift rate of $1.46^{\circ} \pm 0.65^{\circ} \mathrm{My}^{-1}$ during the same time interval based on our computed continental rotation rate and assuming a Pacific Plate paleolongitude of $100^{\circ} \mathrm{W}$ [Fig. 6; Fu and Kent, 2018]. This correspondence between the timing and maximum rate of motion for both the continental and the Pacific Basin plates strongly suggests that whole Earth lithosphere participated in a single rotation.

The coherent motion of the entire Earth surface may be due to relative motion of the lithosphere over the mantle, TPW, or a combination of both processes. The rate of net lithospheric rotation in the past $\sim 130$ My can be quantified using observations of hotspot motion, which yields an average rate of $\sim 0.2^{\circ} \mathrm{My}^{-1}$, with $0.44^{\circ} \mathrm{My}^{-1}$ as an extreme value (Jurdy and Van der Voo, 1974; Gordon and Jurdy, 1986; Gripp and Gordon, 2002). Numerical models broadly agree that typical net rotation rates between the lithosphere and mantle on the modern Earth are expected to be in the $0.1^{\circ}-0.2^{\circ} \mathrm{My}^{-1}$ range (Rudolph and Zhong, 2014). The inferred Late Jurassic monster shift was therefore more than seven times faster than typical documented or theorized cases of net lithosphere rotation relative to the mantle and more than three times faster than the highest proposed value. In contrast, the observed net continental rotation rate of $0.07^{\circ} \pm 0.04^{\circ} \mathrm{My}^{-1}$ between $200 \mathrm{Ma}$ and 170 Ma can be fully explained by relative motion between the lithosphere and underlying mantle and is therefore consistent with the lack of TPW during that earlier time interval.

Velocities of TPW driven by mantle convective flow are controlled by a variety of factors, including the viscous relaxation timescale of the lower mantle, elastic stresses in the lithosphere, and the nature (geometry, magnitude) of the forcing, and accounting for these factors suggests the possibility of TPW of up to 2-3 $\mathrm{My}^{-1}$ on the modern Earth (e.g., Tsai and Stevenson, 2007; Chan et al., 2011). Ongoing TPW in the present-day, driven by a combination of the ongoing effects of the last ice age and modern melting of ice sheets and glaciers proceeds at a rate of $\sim 1^{\circ} \mathrm{My}^{-1}$ (Mitrovica et al., 2015) but net displacements of the pole driven by these processes are small (Chan et al., 2015). Based on comparisons of the observed rotation rate with these expected rates of TPW and relative lithosphere-mantle motion, we conclude that the Late Jurassic monster shift was an episode of TPW associated with mantle convection with minimal contamination from net rotation of the lithosphere relative to the mantle.

The Jurassic monster shift represents the most recent documented episode of TPW with amplitude greater than $20^{\circ}$. Given the relatively reliable knowledge of Earth's surface geography and mantle conditions during the Jurassic compared to earlier proposed time intervals of TPW, the monster shift represents a favorable case study for understanding the mechanisms and consequences of TPW through time. Any plausible driving mechanism for the Jurassic monster shift must be able to explain the apparently sudden onset between $\sim 175$ and 165 Ma when the rate of TPW changed from $\sim 0.07^{\circ} \mathrm{My}^{-1}$ (see above) to at least $1.21^{\circ} \mathrm{My}^{-1}$. Theoretical studies show that TPW events of a similar maximum velocity and total duration may be caused by variations in the rate and geometry of subduction. Specifically, Steinberger and Torsvik (2010) found that TPW velocities of $\sim 1.5^{\circ} \mathrm{My}^{-1}$ may occur under a range of assumptions regarding changes in subduction rate as long as the difference between the maximum and intermediate principal moments of inertia falls to below $\sim 1 / 3$ of the present value. In contrast, models employing a different set of subducted slab and lower mantle dome geometries suggested that rapid TPW with $>2^{\circ} \mathrm{My}^{-1}$ velocity can occur even with large, modern Earth-like differences in the principal moments of inertia (Greff-Lefftz and Besse, 2012, 2014).

Regardless of these differences, existing numerical models suggest that a change in the rate of subduction, even along a single subduction zone, is potentially sufficient to induce TPW at the observed Late Jurassic rates, with a phase shift in time associated with the adjustment of the mantle flow field. Two major Late Jurassic Period continental docking events may have contributed to driving rapid TPW. First, the closure of the Mongol-Okhotsk Ocean basin between China and Siberia would have led to the cessation of subduction along a $\sim 3000 \mathrm{~km}$ front (Van der Voo et al., 2015). However, the resulting perturbation of a detached slab descending through the upper mantle is projected to cause a negative regional geoid anomaly, driving the site of the continental collision towards the spin axis (Greff-Lefftz and Besse, 2014). This predicted sense of motion is the opposite to that observed. However, if the detachment of the subducted slab occurred $\sim 10$ My earlier in the western Mongol-Okhotsk Ocean and assuming a descent rate of $\sim 10 \mathrm{~cm} \mathrm{y}^{-1}$ in the upper mantle (Kravchinsky et al., 2002; Van der Voo et al., 2015), the bulk of the subducted slab may have passed below $1200 \mathrm{~km}$ depth. This would have led to a positive geoid anomaly and rotation of Asia towards the equator during the Late Jurassic in agreement with paleomagnetic data.

It has been suggested that the suture of a ribbon continent composed of the Wrangelia and Stikinia terranes to the western margin of North America occurred during the Late Jurassic to Early Cretaceous interval (Hildebrand, 2013; Sigloch and Mihalynuk, 2013). Unlike the cessation of subduction in the MongolOkhotsk Ocean, the descent of a detached slab in North America would have led to TPW rotation in the correct direction. However, such an event would likely have resulted in the cessation of one subduction zone to the east of the accreting ribbon continent and the initiation of subduction on the west side, the net change induced on the Earth's inertia tensor may be small.

Another potential driver for Jurassic TPW is the descent of accumulated slab material across the $660 \mathrm{~km}$ mantle discontinuity in an event known as a slab avalanche. At a global scale, slab avalanche has been hypothesized to cause intervals of continental growth (Condie, 1998). Meanwhile at the scale of a single plate boundary, such events may have led to the recent reorganization of 
plate boundaries (Pysklywec et al., 2003). A slab avalanche in the western North American margin, for example, could have transferred mass excess from the upper mantle into the lower mantle over the timescale of $<10 \mathrm{My}$ and led to a net negative change in the regional geoid, driving motion towards the pole in agreement with the paleomagnetic data.

Another potential contribution to Late Jurassic TPW is upwelling mantle flow acting in concert with, or independent from, the evolving subduction dynamics. As an example of the latter, the plume that ultimately led to the eruption of the Paraná-Etendeka large igneous province at $\sim 132$ Ma may also have had a nonnegligible impact on the orientation of the rotation axis. However, the relative proximity $\left(\sim 20^{\circ}\right)$ of this large igneous province to the inferred TPW axis may limit its ability to cause large amplitude rotation.

In summary, we find that, without quantitative models including mantle upwellings and realistic slab geometries and descent rates, no unique cause for the Late Jurassic monster shift can be identified, although the cessation of multiple subduction zones at locations favorable for driving TPW at approximately the same time suggests that these events may have played an important role. Because the cessation of subduction was a recurring process throughout the geological past, this possible cause of Late Jurassic TPW implies that the conditions necessary for driving large amplitude TPW existed throughout Earth history and motivates detailed study of early intervals of candidate TPW.

\section{Conclusions}

Our paleomagnetic and geochronological sampling of the La Negra Formation of northern Chile has produced two new paleomagnetic poles for the Late Jurassic Period dated to $165.8 \pm 1.8$ $\mathrm{Ma}$ and $152.8 \pm 0.8 \mathrm{Ma}$. The ages of these poles are well-suited to constrain the amplitude, duration, and, therefore, the rate of polar wander during the Late Jurassic "monster shift." Combined with other recent paleomagnetic results from igneous rock formations, we infer a peak net continental rotation rate of $1.46^{\circ} \pm 0.65^{\circ}$ between 160 and $145 \mathrm{Ma}$ and a mean rate of $1.21^{\circ} \pm 0.35^{\circ} \mathrm{My}^{-1}$ between 170 and $145 \mathrm{Ma}$, producing a net displacement of $25.3^{\circ}$ $\pm 7.3^{\circ}$. This rate is statistically distinguishable from lower, background net continental rotation rates before and after the 165-145 Ma interval. The consistency of this rotation with contemporaneous paleolatitudinal drift of the Pacific Plate, combined with its high velocity, provide strong evidence for the occurrence of TPW during the Late Jurassic.

Given the relative abundance of high-quality paleomagnetic data, constraints on oceanic plate motion, and reliable paleogeographic reconstructions, the Late Jurassic TPW event represents the most robustly identified large amplitude TPW event to-date in the geologic record. The refined rate, timing, and geometry computed for the Late Jurassic event provide a basis for exploring the possible geodynamical drivers of TPW. Future quantitative modeling of subduction and upwelling processes using realistic plate and slab geometries may allow identification of a narrow set of drivers for TPW in the Late Jurassic.

\section{Acknowledgements}

We thank Sean Kinney for helping with the SelFrag® mineral separation, Tanzhuo Liu for help with the Ar-Ar analyses, and Paulina Gonzalez and Jorge Jara for essential help in gathering paleomagnetic samples. We thank Jerry Mitrovica for rewarding discussions. Finally, we thank Dr. Pavel Doubrovine and Dr. Sara Satolli for detailed and constructive reviews. Support for this work came from National Science Foundation Geophysics grant (award number EAR-1723023) and a Lamont-Doherty Earth Observatory Climate Center grant.

\section{Appendix A. Supplementary material}

Supplementary material related to this article can be found online at https://doi.org/10.1016/j.epsl.2019.115835.

\section{References}

Arriagada, C., Roperch, P., Mpodozis, C., Cobbold, P.R., 2008. Paleogene building of the Bolivian Orocline: tectonic restoration of the central Andes in 2-D map view. Tectonics 27, TC6014.

Arriagada, C., Roperch, P., Mpodozis, C., Dupont-Nivet, G., Cobbold, P.R., Chauvin, A., Cortés, J., 2003. Paleogene clockwise tectonic rotations in the forearc of central Andes, Antofagasta region, northern Chile. J. Geophys. Res. 108, 2032.

Besse, J., Courtillot, V., 2002. Apparent and true polar wander and the geometry of the geomagnetic field over the last 200 Myr. J. Geophys. Res. 107, 2300.

Biggin, A.J., van Hinsbergen, D.J.J., Langereis, C.G., Straathof, G.B., Deenen, M.H.L., 2008. Geomagnetic secular variation in the Cretaceous Normal Superchron and in the Jurassic. Phys. Earth Planet. Inter. 169, 3-19. https://doi.org/10.1016/j. pepi.2008.07.004.

Bryan, P., Gordon, R.G., 1990. Rotation of the Colorado Plateau: an updated analysis of paleomagnetic poles. Geophys. Res. Lett. 17, 1501-1504.

Buchelt, M., Tellez Cancino, C., 1988. The Jurassic La Negra Formation in the area of Antofagasta, Northern Chile (lithology, petrography, geochemistry). In: The Southern Central Andes. In: Lecture Notes in Earth Sciences. Springer-Verlag, Berlin, Heidelberg, pp. 171-182.

Chan, N.-H., Mitrovica, J.X., Daradich, A., 2015. Did glacially induced TPW end the ice age? A reanalysis. Geophys. J. Int. 202, 1749-1759.

Chan, N.-H., Mitrovica, J.X., Daradich, A., Creveling, J.R., Matsuyama, I., Stanley, S., 2014. Time-dependent rotational stability of dynamic planets with elastic lithospheres. J. Geophys. Res., Planets 119, 169-188.

Chan, N.-H., Mitrovica, J.X., Matsuyama, I., Latychev, K., Creveling, J.R., Stanley, S., Morrow, E., 2011. The rotational stability of a convecting Earth: the Earth's figure and TPW over the last 100 Myr. Geophys. J. Int. 187 (2), 773-782.

Clement, B.M., 2004. Dependence of the duration of geomagnetic polarity reversals on site latitude. Nature 428, 637-640.

Cogné, J.-P., Kravchinsky, V.A., Halim, N., Hankard, F., 2005. Late Jurassic-Early Cretaceous closure of the Mongol-Okhotsk Ocean demonstrated by new Mesozoic palaeomagnetic results from the Trans-Baikal area (SE Siberia). Geophys. J. Int. $163,813-832$.

Condie, K.C., 1998. Episodic continental growth and supercontinents: a mantle avalanche connection? Earth Planet. Sci. Lett. 163, 97-108.

Creveling, J.R., Mitrovica, J.X., Chan, N.-H., Latychev, K., Matsuyama, I., 2012. Mechanisms for oscillatory true polar wander. Nature 491, 244-248.

Cromwell, G., Johnson, C.L., Tauxe, L., Constable, C.G., Jarboe, N.A., 2018. PSV10: a global data set for 0-10 Ma time-averaged field and paleosecular variation studies. Geochem. Geophys. Geosyst. 19, 1533-1558.

Dalrymple, G.B., Alexander, E.C., Lanphere, M.A., Kraker, G.P., 1981. Irradiation of Samples for ${ }^{40} \mathrm{Ar} /{ }^{39} \mathrm{Ar}$ Dating Using the Geological Survey TRIGA Reactor. Geological Survey Professional Paper 1176.

Doubrovine, P.V., Veikkolainen, T., Pesonen, L.J., Piispa, E., Ots, S., Smirnov, A.V., Kulakov, E.V., Biggin, A.J., 2019. Latitude dependence of geomagnetic paleosecular variation and its relation to the frequency of magnetic reversals: observations from the cretaceous and Jurassic. Geochem. Geophys. Geosyst. 20, 1240-1279.

Eagles, G., 2007. New angles on South Atlantic opening. Geophys. J. Int. 168, $353-361$.

Evans, D.A.D., 2003. True polar wander and supercontinents. Tectonophysics 362, 303-320.

Fu, R.R., Kent, D.V., 2018. Anomalous Late Jurassic motion of the Pacific Plate with implications for true polar wander. Earth Planet. Sci. Lett. 490, 20-30.

Goguitchaichvili, A., Alva-Valdivia, L.M., Urrutia-Fucugauchi, J., 2003. Paleomagnetism and rock magnetism of the Jurassic La Negra Formation, Northern Chile: implications for tectonics and volcanic stratigraphy. Int. Geol. Rev. 45, 563-573.

Gold, T., 1955. Instability of the Earth's axis of rotation. Nature 175, 526-529.

Gordon, R.G., 1995. Plate motions, crustal and lithospheric mobility, and paleomagnetism: prospective viewpoint. J. Geophys. Res. 100, 24,367-24,392.

Gordon, R.G., Jurdy, D.M., 1986. Cenozoic global plate motions. J. Geophys. Res. 91, $12,389-12,406$.

Greff-Lefftz, M., Besse, J., 2014. Sensitivity experiments on True Polar Wander. Geochem. Geophys. Geosyst. 15, 4599-4616.

Greff-Lefftz, M., Besse, J., 2012. Paleo movement of continents since $300 \mathrm{Ma}$ mantle dynamics and large wander of the rotational pole. Earth Planet. Sci. Lett. 345-348, 151-158.

Gripp, A.E., Gordon, R.G., 2002. Young tracks of hotspots and current plate velocities. Geophys. J. Int. 150, 321-361.

Gross, R.S., Vondrak, J., 1999. Astrometric and space-geodetic observations of polar wander. Geophys. Res. Lett. 26, 2085-2088. 
Halvorsen, Erik, 1989. A paleomagnetic pole position of Late Jurassic/Early Cretaceous dolerites from Hinlopenstretet, Svalbard, and its tectonic implications. Earth Planet. Sci. Lett. 94 (3-4), 398-408.

Handschumacher, D.W., Sager, W.W., Hilde, T.W.C., Bracey, D.R., 1988. Pre-Cretaceous tectonic evolution of the Pacific plate and extension of the geomagnetic polarity reversal time scale with implications for the origin of the Jurassic "Quiet Zone". Tectonophysics 155, 365-380.

Hargraves, R.B., 1989. Paleomagnetism of Mesozoic kimberlites in southern Africa and the Cretaceous apparent polar wander curve for Africa. J. Geophys. Res. 94, $1851-1866$.

Hargraves, R.B., Rehacek, J., Hooper, P.R., 1997. Paleomagnetism of the Karoo igneous rocks in southern Africa. S. Afr. J. Geol. 100, 195-212.

Hildebrand, R.S., 2013. Mesozoic Assembly of the North American Cordillera. Geological Society of America Special Papers. Geological Society Special Publications.

Iglesia Llanos, M.P., Lanza, R., Riccardi, A.C., Geuna, S., Laurenzi, M.A., Ruffini, R., 2003. Palaeomagnetic study of the El Quemado complex and Marifil formation, Patagonian Jurassic igneous province, Argentina. Geophys. J. Int. 154, 599-617.

Jurdy, D.M., Van der Voo, R., 1974. A method for the separation of true polar wander and continental drift, including results for the last 55 m.y. J. Geophys. Res. 79, $2945-2952$.

Kent, D.V., Irving, E., 2010. Influence of inclination error in sedimentary rocks on the Triassic and Jurassic apparent pole wander path for North America and implications for Cordilleran tectonics. J. Geophys. Res. 115, B10103.

Kent, D.V., Kjarsgaard, B.A., Gee, J.S., Muttoni, G., Heaman, L.M., 2015. Tracking the Late Jurassic apparent (or true) polar shift in U-Pb-dated kimberlites from cratonic North America (Superior Province of Canada). Geochem. Geophys. Geosyst. 16, 983-994.

Kent, D.V., Tauxe, L., 2005. Corrected late Triassic latitudes for continents adjacent to the North Atlantic. Science 307, 240-244.

Kent, D.V., Witte, W.K., 1993. Slow apparent polar wander for North America in the Late Triassic and large Colorado Plateau rotation. Tectonics 12, 291-300.

Kirschvink, J.L., 1980. The least-squares line and plane and the analysis of paleomagnetic data: examples from Siberia and Morocco. Geophys. J. R. Astron. Soc. 62, 699-718.

König, M., Jokat, W., 2006. The Mesozoic breakup of the Weddell Sea. J. Geophys. Res. 111, B12102.

Kramer, W., Siebel, W., Romer, R.L., Haase, G., Zimmer, M., Ehrlichmann, R., 2005. Geochemical and isotopic characteristics and evolution of the Jurassic volcanic arc between Arica $\left(18^{\circ} 30^{\prime} \mathrm{S}\right)$ and Tocopilla $\left(22^{\circ} \mathrm{S}\right)$, North Chilean Coastal Cordillera. Chem. Erde 65, 47-78. https://doi.org/10.1016/j.chemer.2004.01.002.

Kravchinsky, V.A., Sorokin, A.A., Courtillot, V., 2002. Paleomagnetism of Paleozoic and Mesozoic sediments from the southern margin of Mongol-Okhotsk ocean, far eastern Russia. J. Geophys. Res. 107, 2253.

Kuiper, K.F., Deino, A., Hilgen, F.J., Krijgsman, W., Renne, P.R., Wijbrans, J.R., 2008. Synchronizing rock clocks of Earth history. Science 320, 500-504.

Larson, R.L., Steiner, M.B., Erba, E., Lancelot, Y., 1992. Paleolatitudes and tectonic reconstructions of the oldest portion of the Pacific plate: a comparative study In: Proc., Scientific Results, ODP, Leg 129, Old Pacific Crust, pp. 615-631.

Lee, J.-Y., Marti, K., Severinghaus, J.P., Kawamura, K., Yoo, H.-S., Lee, J.B., Kim, J.S., 2006. A redetermination of the isotopic abundances of atmospheric Ar. Geochim. Cosmochim. Acta 70, 4507-4512.

Lottes, A.L., Rowley, D.B., 1990. Reconstruction of the Laurasian and Gondwanan segments of Permian Pangaea. In: Palaeozoic Palaeogeography and Biogeography, Geological Society Memoir, pp. 383-395.

Lucassen, F., Kramer, W., Bartsch, V., Wilke, H.-G., Franz, G., Romer, R.L., Dulski, P. 2006. $\mathrm{Nd}, \mathrm{Pb}$, and $\mathrm{Sr}$ isotope composition of juvenile magmatism in the Mesozoic large magmatic province of northern Chile $\left(18-27^{\circ} \mathrm{S}\right)$ : indications for uniform subarc mantle. Contrib. Mineral. Petrol. 152, 571-589.

Maloof, A.C., Halverson, G.P., Kirschvink, J.L., Schrag, D.P., Weiss, B.P., Hoffmann, P.F., 2006. Combined paleomagnetic, isotopic, and stratigraphic evidence for true polar wander from the Neoproterozoic Akademikerbreen Group, Svalbard, Norway. Geol. Soc. Am. Bull. 118, 1099-1124.

McFadden, P.L., McElhinny, M.W., 1990. Classification of the reversal test in paleomagnetism. Geophys. J. Int. 103, 725-729.

Medina, E., 2012. Cartas Tocopilla y María Elena, Región de Antofagasta, Servicio Nacional de Geología y Minería, Carta Geológica de Chile, Serie Geología Básica 141-142, 1 mapa escala 1:100.000. Santiago.

Mitchell, R.N., Evans, D.A.D., Kilian, T.M., 2010. Rapid Early Cambrian rotation of Gondwana. Geology 38, 755-758. https://doi.org/10.1130/G30910.1.

Mitrovica, J.X., Hay, C.C., Morrow, E., Kopp, R.E., Dumberry, M., Stanley, S., 2015 Reconciling past changes in Earth's rotation with 20th century global sea-level rise: resolving Munk's enigma. Sci. Adv. 1, e1500679.

Mound, J.E., Mitrovica, J.X., 1998. True polar wander as a mechanism for secondorder sea-level variation. Science 279, 534-537.

Mound, J.E., Mitrovica, J.X., Evans, D.A.D., Kirschvink, J.L., 1999. A sea-level test for inertial interchange true polar wander events. Geophys. J. Int. 136, F5-F10.

Muttoni, G., Dallanave, E., Channell, J.E.T., 2013. The drift history of Adria and Africa from $280 \mathrm{Ma}$ to Present, Jurassic true polar wander, and zonal climate control on Tethyan sedimentary facies. Palaeogeogr. Palaeoclimatol. Palaeoecol. 386, 415-435.
Muttoni, G., Kent, D.V., 2019. Jurassic monster polar shift confirmed by sequential paleopoles from Adria, promontory of Africa. J. Geophys. Res., Solid Earth 124, 3288-3306.

Muttoni, G., Kent, D.V., 2016. A novel plate tectonic scenario for the genesis and sealing of some major Mesozoic oil fields. GSA Today 26, 4-10. https://doi.org/ 10.1130/GSATG289A.1.

Muttoni, G., Kent, D.V., Garzanti, E., Brack, P., Abrahamsen, N., Gaetani, M., 2003. Early Permian Pangea 'B' to Late Permian Pangea 'A'. Earth Planet. Sci. Lett. 215, 379-394.

Nürnberg, D., Müller, R.D., 1991. The tectonic evolution of the South Atlantic from Late Jurassic to present. Tectonophysics 191, 27-53.

O'Connell, R.J., Hager, B.H., 1990. Toroidal-poloidal partitioning of lithospheric plate motions. In: Glacial Isostasy, Sea-Level and Mantle Rheology. Kluwer Academic Publishers, pp. 535-551.

Oliveros, V., Féraud, G., Aguirre, L., Fornari, M., Morata, D., 2006. The Early Andean Magmatic Province (EAMP): ${ }^{40} \mathrm{Ar} /{ }^{39} \mathrm{Ar}$ dating on Mesozoic volcanic and plutonic rocks from the Coastal Cordillera, northern Chile. J. Volcanol. Geotherm. Res. 157, 311-330.

Opdyke, N.D., Kent, D.V., Foster, D.A., Huang, K., 2015. Paleomagnetism of Miocene volcanics on Sao Tome: paleosecular variation at the Equator and a comparison to its latitudinal dependence over the last 5 My. Geochem. Geophys. Geosyst. 16, 3870-3882.

Palmer, H.C., Hayatsu, A., MacDonald, W.D., 1980. The Middle Jurassic Camaraca Formation, Arica, Chile: palaeomagnetism, $\mathrm{K}-\mathrm{Ar}$ age dating and tectonic implications. Geophys. J. R. Astron. Soc. 62, 155-172.

Pichowiak, S., Buchelt, M., Damm, K.-W., 1990. Magmatic Activity and Tectonic Setting of the Early Stages of the Andean Cycle in Northern Chile. GSA Special Paper, vol. 241, pp. 127-144.

Pysklywec, R.N., Mitrovica, J.X., Ishii, M., 2003. Mantle avalanche as a driving force for tectonic reorganization in the southwest Pacific. Earth Planet. Sci. Lett. 209, 29-38.

Robert, B., Greff-Lefftz, M., Besse, J., 2018. True polar wander: a key indicator for plate configuration and mantle convection during the late neoproterozoic. Geochem. Geophys. Geosyst. 19, 3478-3495.

Rogers, G., Hawkesworth, C.J., 1989. A geochemical traverse across the North Chilean Andes: evidence for crust generation from the mantle wedge. Earth Planet. Sci. Lett. 91, 271-285.

Rousse, S., Gilder, S., Farber, D., McNulty, B., Torres, V.R., 2002. Paleomagnetic evidence for rapid vertical-axis rotation in the Peruvian Cordillera ca. $8 \mathrm{Ma}$. Geol. Soc. Am. Bull. 30, 75-78.

Rudolph, M.L., Zhong, S.J., 2014. History and dynamics of net rotation of the mantle and lithosphere. Geochem. Geophys. Geosyst. 15

Ruiz González, V., Puigdomenech, C.G., Renda, E.M., Boltshauser, B., Somoza, R., Vizán, H., Zaffarana, C.B., Taylor, G.K., Haller, M., Fernández, R., 2019. New paleomagnetic pole for the Upper Jurassic Chon Aike Formation of southern Argentina (South America): testing the tectonic stability of Patagonia with respect to South America, and implications to Middle Jurassic-Early Cretaceous true polar wander. Tectonophysics 750, 45-55.

Schmidt, P.W., 1982. Linearity spectrum analysis of multi-component magnetizations and its application to some igneous rocks from southeastern Australia. Geophys. J. R. Astron. Soc. 70, 647-665.

SERNAGEOMIN, 2003. Mapa Geológico de Chile.

Seton, M., Müller, R.D., Zahirovic, S., Gaina, C., Torsvik, T.H., Shephard, G., Talsma, A., Gurnis, M., Turner, M., Maus, S., Chandler, M., 2012. Global continental and ocean basin reconstructions since 200 Ma. Earth-Sci. Rev. 113, 212-270.

Sigloch, K., Mihalynuk, M.G., 2013. Intra-oceanic subduction shaped the assembly of Cordilleran North America. Nature 496, 50-57.

Steinberger, B., Torsvik, T.H., 2010. Toward an explanation for the present and past locations of the poles. Geochem. Geophys. Geosyst. 11, Q06W06.

Steiner, M., Ogg, J., Sandoval, J., 1987. Jurassic magnetostratigraphy, 3. BathonianBajocian of Carcabuey, Sierra Harana and Campillo de Arenas (Subbetic Cordillera, southern Spain). Earth Planet. Sci. Lett. 82, 357-372.

Steiner, M.B., 2003. A cratonic Middle Jurassic paleopole: Callovian-Oxfordian stillstand (J-2 cusp), rotation of the Colorado Plateau, and Jurassic North American apparent polar wander. Tectonics 22, 1020.

Steiner, M.B., 1988. Paleomagnetism of the Late Pennsylvanian and Permian: a test of the rotation of the Colorado Plateau. J. Geophys. Res. 93, 2201-2215.

Swanson-Hysell, N.L., Maloof, A.C., Kirschvink, J.L., Evans, D.A.D., Halverson, G.P. Hurtgen, M.T., 2012. Constraints on Neoproterozoic paleogeography and Paleozoic orogenesis from paleomagnetic records of the Bitter Springs Formation, Amadeus Basin, central Australia. Am. J. Sci. 312, 817-884.

Tominaga, M., Sager, W.W., Tivey, M.A., Lee, S.M., 2008. Deep-tow magnetic anomaly study of the Pacific Jurassic Quiet Zone and implications for the geomagnetic polarity reversal timescale and geomagnetic field behavior. J. Geophys. Res., Solid Earth 113, B07110. https://doi.org/10.1029/2007JB005527.

Torsvik, T.H., Müller, R.D., Van der Voo, R., Steinberger, B., Gaina, C., 2008. Global plate motion frames: toward a unified model. Rev. Geophys. 46, RG3004.

Torsvik, T.H., Rousse, S., Labails, C., Smethurst, M.A., 2009. A new scheme for the opening of the South Atlantic Ocean and the dissection of an Aptian salt basin. Geophys. J. Int. 177, 1315-1333. 
Torsvik, T.H., Steinberger, B., Gurnis, M., Gaina, C., 2010. Plate tectonics and net lithosphere rotation over the past 150 My. Earth Planet. Sci. Lett. 291, 106-112.

Torsvik, T.H., Van der Voo, R., Preeden, U., Mac Niocaill, C., Steinberger, B., Doubrovine, P.V., van Hinsbergen, D.J.J., Domeier, M., Gaina, C., Tohver, E., Meert, J.G., McCausland, P.J.A., Cocks, L.R.M., 2012. Phanerozoic polar wander, palaeogeography and dynamics. Earth-Sci. Rev. 114, 325-368.

Tsai, V.C., Stevenson, D.J., 2007. Theoretical constraints on true polar wander. J. Geophys. Res. 112, B05415. https://doi.org/10.1029/2005JB003923.

Van der Voo, R., 1994. True polar wander during the middle Paleozoic. Earth Planet. Sci. Lett. 122, 239-243.

Van der Voo, R., van Hinsbergen, D.J.J., Domeier, M., Spakman, W., Torsvik, T.H., 2015. Latest Jurassic-earliest Cretaceous closure of the Mongol-Okhotsk Ocean: a paleomagnetic and seismological-tomographic analysis. In: Anderson, T.H., Didenko, A.N., Johnson, C.L., Khanchuk, A.I., MacDonal, J.H. (Eds.), Late Jurassic Margin of Laurasia-A Record of Faulting Accommodating Plate Rotation.

Van Fossen, Mickey C., Kent, Dennis V., 1990. High-latitude paleomagnetic poles from Middle Jurassic plutons and moat volcanics in New England and the controversy regarding Jurassic apparent polar wander for North America. J. Geophys. Res., Solid Earth 95 (B11), 17503-17516.

Van Fossen, M.C., Kent, D.V., 1993. A palaeomagnetic study of 143 Ma kimberlite dikes in central New York State. Geophys. J. Int. 113, 175-185. 